\title{
HR Practices and Job Performance
}

\author{
Devender Singh Muchhal \\ Research Associate, University School of Management, Kurukshetra University, Kurukshetra, \\ Haryana (136119) - India
}

\begin{abstract}
HR Practices are the most important tools of any organization to fulfill majority of the organizational goals via better job performance of the employees working in the organization. The present study was designed to study the nature and pattern of relationship between HR practices (Compensation, Performance Evaluation process \& promotion) and job performance of the employees in industrial set up. Questionnaires consisting of 15 items (HR practices) and 14 items (Job performance) were used. The findings of the present study reveals that HR practices i.e. job performance in organization are correlated with HR practices (compensation, performance evaluation process \& promotion practices).
\end{abstract}

\section{Introduction:}

Organizations are today facing increasingly competitive challenges to achieve the organizational goals. To be successful, a firm must be able to improve performance by reducing costs, creating new products and processes, enhancing quality and productivity, increasing speed to market (Luthans \& Sommers, 2005). Thus organizations need to focus on capabilities of their workforce/working in organization towards common goals. Harter etal (2002) suggested that effective management of a firm's human resources would be able to generate and increase knowledge, motivation, synergy, and commitment to achieve competitive advantage for the firm. HRM practices more or less create conditions where employees become highly involved in the organization and work hard to accomplish the organization's goals.

Many researches shows positive association between HR practices and employees' performance (Wright et al., 2003, Tessema and Soeters, 2006, Park et al., 2003). Organizations having qualified and experienced manpower gives competitive edge and it is said to be most sustainable source of competitive advantage. Harel and Tzafrir (1996) observed that HRM activities can affect an organization's performance via employee skills and quality (selection and training), employee motivation (incentive compensation). HRM practices enhance organizational effectiveness and performance by attracting, identifying, and retaining employees with knowledge, skills, and abilities, and getting employees to behave in a manner which further supports the mission and objectives of the organization. Hence, the effectiveness of HRM practices depends on how it creates the appropriate attitudes and behaviours in employees, along with its implementation.

\section{Job Performance}

Organizations need highly performing individuals in order to meet their goals, to deliver the products and services they are specialized in, and finally to achieve competitive advantage. Performance is also important for the individual. Accomplishing tasks and performing at a high level can be a source of satisfaction, with feelings of mastery and pride. Low performance and not achieving the goals might be experienced as dissatisfying or even as a personal failure. Different authors have defined performance as "observable things people do (i.e., behaviors) that are relevant for the goals of the organization". Performance is a significant concept because, "the major contribution of an employee's worth to the organization is through work behaviour and ultimately performance" (Arvey \& Murphy, 1998). Job performance is also defined as the degree to which an individual executes his or her role with reference to certain specified standards set by the organizations (Nayyar, 1994). Romanoff, (1989) stated that performance is a set of outcomes produced during a certain period of time, and does not refer to traits or personal characteristics of the performer.

However, authors agree that when conceptualizing performance one has to differentiate between an action (i.e., behavioral) aspect and an outcome aspect of performance (Kanfer \& Ackerman, 1989 and Roe, 1999).The behavioral aspect refers to what an individual does in the work situation it encompasses behaviors which are relevant for the organizational goals. Further, "Performance is what the organization hires one to do, and do well". Thus, performance is not defined by the action itself but by judgmental and evaluative processes (I1gen \& Schneider, 1991; Motowidlo etal., 1997). The outcome aspect refers to the consequence or result of the individual's behavior. In many situations, the behavioral and outcome aspects are related empirically, but they do not overlap completely. Outcome aspects of performance depend also on factors other than the individual's behavior. Despite the general agreement that the behavioral and the outcome aspect of 
performance have to be differentiated, authors do not completely agree about which performance concepts and performance theory of these two aspects should be labeled 'performance'. Campbell et al., (1993) rightly said that performance is a construct that has received very little research or theoretical attention. There are two possible reasons for this: 1) performance has always been treated as the dependent variable, understanding performance itself has not been very exciting, since the independent variables generated the' most professional and/or scientific interest in the literature; 2) definition of performance and designation of its indicators seemed to be out of our hands.

It has been rightly pointed out by Viswesvaran and Ones, (2000) that Job Performance is the core construct of today's work -setting and which in turn making it an important research problem thus knowing details of the concept gains importance. It shows how good or bad the employees are working, what are the specific training programs that should be designed for them. Moreover, most of the placement decision depend on the job performance. It can be said that performance will not loose it attractiveness in the years to come because it is the major contribution to organization made by the employees. Job performance is also defined as the degree to which an individual executes his or her role with reference to certain specified standards set by the organizations.

Performance is a multi-dimensional concept. On the most basic level, Borman \& Motowidlo, (1993) distinguish between task and contextual performance. Three basic assumptions are associated with the differentiation between task and contextual performance (Borman \& Motowidlo, 1997): Activities relevant for task performance vary between jobs whereas contextual performance activities are relatively similar across jobs; Task performance is related to ability, whereas contextual performance is related to personality and motivation; Task performance is more prescribed and constitutes in-role behavior, whereas contextual performance is more discretionary and extra- role.

Task performance refers to an individual's proficiency with which he or she performs activities which contribute to the organization's 'technical core'. This contribution can be both direct (e.g. in the case of production workers), or indirect (e.g. in the case of managers or staff personnel). Task performance in itself is multi-dimensional; there are five factors which refer to task performance (Campbell et al, 1996; and Motowidlo \& Schmit, (1999) such as job-specific task proficiency, non-job-specific task proficiency, written and oral communication proficiency, supervision-in the case of a supervisory or leadership position-and artly management/administration. Contextual performance refers to activities which do not contribute to the technical core but which support the organizational, social and psychological environment in which organizational goals are pursued. Contextual performance includes not only behaviors such as helping coworkers or being a reliable member of the organization, but also making suggestions about how to improve work procedures. Researchers have developed a number of contextual performance concepts. On a very general level, one can differentiate between two types of contextual performance: behaviors which aim primarily at the smooth functioning of the organization as it is at the present moment, and pro active behaviors which aim at changing and improving work procedures and organizational processes. The 'stabilizing' contextual performance behaviors include organizational citizenship behavior with its five components altruism, conscientiousness, civic virtue, courtesy, and sportsmanship (Organ, 1988). Thus, contextual- performance is not a single set of uniform behaviors, but is in itself a multidimensional concept. Organizations and work as a whole are undergoing dramatic changes Cooper\&Jackson,1997;Howard,1995) which have implications for conceptualizing and understanding performance (Ilgen \& Pulakos, 1999). Major trends that have affected the performance include the importance of continuous learning, the relevance of proactivity, increase in teamwork, globalization and technology. Now it is accepted that employees create an important source of competitive advantage for firms (Barney, 1991). As a result, it is important that a firm adopts HRM practices that make the best use of its employees. Also, a number of studies have represented a positive relationship between so called 'high performance work practices' (Huselid, 1995) and different measures of organizational performance.

\section{Literature Review:}

A brief review of research exhibits the relationship between HR Practices and Job performance was conducted which has been summarized below:

Huselid (1995) conducted a research after taking eleven HRM practices (personnel selection, labor management participation, incentive compensation, performance appraisal, grievance procedures, information sharing, job design, attitude assessment, recruitment efforts, promotion criteria and employee training) and reported significant relationship between high work practices such as compensation and employees outcomes. Delery and Doty, (1996) demonstrated that three approaches have been used to examine the link between HRM practices and performance. They are the contingency, configurational and universalistic approaches. Teseema \& Soeters (2006) conducted research on eight HRM practices (recruitment and selection practices, placement practices, training practices, compensation practices, employee performance evaluation practices, promotion 
practices, grievance procedure and pension or social security). They found a significant relationship between HRM practices and perceived employee performance.Shezad et al.(2008) conducted a research on HRM practices (compensation, promotion and performance evaluation practices) and on perceived performance of university teachers of Pakistan. and their findings reveal that compensation and promotion practices were found to be significantly correlated with perceived performance of university teachers of Pakistan. Performance evaluation practice was found to be insignificantly correlated with the performance of university teachers of Pakistan.Baloch et al. (2010) conducted his research on HRM practices to examine their relationship with the perceived performance of employees in private and public sector banks of NWFP. Compensation, promotion and performance evaluation practices were significantly found to be correlated with employee performance and suggested that banks are encouraged to pay proper attention to these three practices. Sohrab Ahmad and Khurram Shezad (2011) did a study on the impact of compensation, promotion and performance evaluation practices on the performance of university teachers of Jammu and Kashmir. Authors concluded that compensation has strong and positive impact on performance of university teachers of $\mathrm{J} \& \mathrm{~K}$. Compensation is the major element to influence teachers. The more teachers are compensated fairly the more they will perform better. On the other hand the performance evaluation and promotion practices were insignificant with the performance of university teachers of $J \& K$. The reason for this is most promotion and performance evaluation procedures are vague and not properly practiced.

Grossman (2000) proposed 10 key performance indicators for human capital as revenue factor, voluntary separation rate ,human capital value added, human capital ROI, total compensation revenue percent, total labor cost revenue percent, training investment factor, cost per hire,. health care costs per employee, turnover costs. Zwell \& Ressler (2000) categorized the key performance indicators for human capital into basic skills for all key positions, managerial skills and senior management skills.Stewart (2001) measures the efficiency of human capital. His measures include average year of service, average education level,. \% with advanced degrees, hiring cost, IT literacy, hours of training/employee, employee satisfaction, , employee turnover(separation), innovation ability, new colleague-to-colleague, relationships spawned. success of employee-suggestion program, value-added/employee. Pablos (2002) use indicators such as employee overview , employee shift, education, promise and motivation, training result. PwC (2008) elements of human capital include leadership ability, employment contracts, talent management, learning and innovation. Gimeno et al. (1997) found a positive association between the overall level of human capital, as measured by education level and work experience, and economic performance at both the entrepreneur's level and the firm's level. Brüderl et al. (1991) founds that greater entrepreneurial human capital enhances the productivity of the founder, which results in higher profits and, therefore, lower probability of early exit. Higher productivity of the founder means the business owner is more efficient in organizing and managing operations or is able to attract more customers, negotiate better contracts with suppliers and raise more capital from investors. Hence on the basis of above Literature review, the current study was designed to study the relationship between HR practices \& Job Performance.

Objectives:

1. To study the relationship between HR Practices (Compensation, Performance Evaluation processes \& Promotion \& Job performance.

III. Research Methodology: Sample:

To fulfil the above mentioned objectives, following research methodology was used:

A sample of 512 respondents working in Steel \& Power industries of Chhattisgarh was drawn by Convenient Sampling Method. The age of the respondents ranged between 21 to 55 years Majority of the respondents were BE/ B. Tech qualified.

Tools:

A. HR Practices:

The questionnaire for HR practices consists of 15 items comprising of three HR practice measure viz. Compensation, Performance Evaluation process \& Promotion, which was based on 5 point Likert scale (Strongly disagree to strongly agree) developed by Teseema \& Soeters (2006).

\section{B. Job Performance:}

The job performance of the subjects was assessed through Singh \& Pestonjees (1988) Performance Rating Scale. It is a Likert type scale consisting of 14 items with five response alternatives. The immediate senior is required to rate how a particular subordinate was doing on the job areas included in the scale. The scale covered 14 areas of work performance viz. quality of work performance, amount of effort expanded on the job, 
speed on job, quality of the work, capacity of work performance, care in handling company property, ability to work without supervision, ability to handle different jobs, dependability, ability to get along with others, attendance \& punctuality, planning ability, initiative on the job and overall work performance. The reported Cronback's coefficient alpha of the scale is 0.99 , which indicate high level reliability of the scale. The index of homogeneity and internal validity of the items were tested by point biserial correlation. The correlation between actual performance and the scores on this scale was found to be $0.84(\mathrm{~N}=200)$.

\section{Administration of the Tests:}

The tests used in the present study were administered individually to all the subjects. The selected subjects were contacted at their respective working place as well as residence and their willingness to participate in the study was sought. Since subjects were interested to participate in the testing only during their vacant time, they were tested individually whenever they were free form their duties. At the initial stage, tests of HR practices and performance administered. The tests were administered in accordance with the procedure described by the test authors.The self rating by the respondents was obtained regarding job performance. The performance rating scale(PRS) provided scores on a five point rating scale. Raters provided rating of performance by assigning a score from 1 to 5 as per one's real performance on each of the 14 areas.

\section{Statistical Analysis}

The obtained data were processed for the computation of Mean, S.D., Skewness, Kurtosis, Pearson's correlation.

\section{Results \& Analysis:}

In order to fulfill the main research objectives of the present study, the obtained, data were processed for the computation of means, Standard Deviations, Skewness, Kurtosis and Pearson's correlation.

\section{Descriptive Statistics:}

The collected data were analyzed with the help of descriptive statistics. Skewness and Kurtosis describe the pattern of score of distribution. The scores of employees on 17 variables including 3 of HR Practices viz (compensation, performance evaluation process \& promotion) and 14 of job performance (i.e. quality of work performance, amount of effort expanded on the job, speed on job, quality of the work, capacity of work performance, care in handling company property, ability to work without supervision, ability to handle different jobs, dependability, ability to get along with others, attendance \& punctuality, planning ability, initiative on the job and overall work performance) have been shown in table 1. All the measures of job performance (i.e. quality of work performance, amount of effort expanded on the job, speed on job, quality of the work, capacity of work performance, care in handling company property, ability to work without supervision, ability to handle different jobs, dependability, ability to get along with others, attendance \& punctuality, planning ability, initiative on the job and overall work performance) and two measures of HR practices i.e. performance evaluation process and promotion are negatively skewed, where as one measure of HR practices (compensation) is positively skewed. Careful inspection of mean of HR practices variables shows that employees working in steel and power sector in the region of Chhattisgarh are scoring above then average on all the variables, suggesting thereby that they are better on almost all the variables of HR practices. Similarly, they also tend to be in moderate level of compensation $(\mathrm{M}=222.76)$. An inspection of correlation matrix table 2 reveals that interrcorrelation among HR practices variables range between 0.471 to 0.614 . All the intercorrelations are positive and significant at 0.01 level, Association among these measures show that all the measures share their variances among themselves. Intercorrelation among the measures of job performance range between 0.132 to 0.632 . All the intercorrelation are positive and significant at 0.01 level. Intercorrelation between the 3 measures of HR practices and 14 of job performance range between 0.132 to 0.632 . Out of 42 intercorrelations 36 are significant at 0.01 level.

Compensation as measure of HR practices correlates with quality of work performance $(.217 \mathrm{p}<.01)$, amount of effort expanded on the job $(.265 \mathrm{p}<.01)$, speed on job $(.252 \mathrm{p}<.01)$, quality of the work $(.226 \mathrm{p}<$ $.01)$, capacity of work performance $(.286 \mathrm{p}<.01)$, care in handling company property $(.249 \mathrm{p}<.01)$, ability to work without supervision $(.207 \mathrm{p}<.01)$, ability to handle different jobs $(.172 \mathrm{p}<.01)$, attendance \& punctuality $(.175 \mathrm{p}<.01)$, planning ability $(.266 \mathrm{p}<.01)$, initiative on the job $(.156 \mathrm{p}<.01)$ and overall work performance $(.333 \mathrm{p}<.01)$ Performance Evaluation Process as measure of HR practices correlates with quality of work performance $(.242 \mathrm{p}<.01)$, amount of effort expanded on the job $(.343 \mathrm{p}<.01)$, speed on job $(.371 \mathrm{p}<.01)$, quality of the work $(.267 \mathrm{p}<.01)$, capacity of work performance $(.297 \mathrm{p}<.01)$, care in handling company property $(.326 \mathrm{p}<.01)$, ability to work without supervision $(.144 \mathrm{p}<.01)$, ability to handle different jobs $(.159 \mathrm{p}$ $<.01)$, ability to get along with others $(.116 \mathrm{p}<.01)$, attendance \& punctuality $(.194 \mathrm{p}<.01)$, planning ability $(.338 \mathrm{p}<.01)$, initiative on the job $(. .295 \mathrm{p}<.01)$ and overall work performance $(.320 \mathrm{p}<.01)$.Promotion as 
measure of HR practices correlates with quality of work performance $(.115 \mathrm{p}<.01)$, amount of effort expanded on the job $(.194 \mathrm{p}<.01)$, speed on job $(.151 \mathrm{p}<.01)$, quality of the work $(.117 \mathrm{p}<.01)$, capacity of work performance $(.170 \mathrm{p}<.01)$, care in handling company property $(.136 \mathrm{p}<.01)$, ability to get along with others $(.164 \mathrm{p}<.01)$, attendance \& punctuality $(.164 \mathrm{p}<.01)$, planning ability $(.188 \mathrm{p}<.01)$, initiative on the job $(.157 \mathrm{p}<.01)$ and overall work performance $(.178 \mathrm{p}<.01)$

The significant intercorrelations between three measures of HR practices viz. compensation, performance evaluation process \& promotion and 14 of job performance viz. quality of work performance, amount of effort expanded on the job, speed on job, quality of the work, capacity of work performance, care in handling company property, ability to work without supervision, ability to handle different jobs, dependability, ability to get along with others, attendance \& punctuality, planning ability, initiative on the job and overall work performance reveals that these measures share most of their variances with fourteen measures of job performance.

\section{Discussion:}

The present study states that HR practice measure compensation and Job performance measures viz. quality of work performance, amount of effort expanded on the job, speed on job, quality of the work, capacity of work performance, care in handling company property, ability to work without supervision, ability to handle different jobs, attendance \& punctuality, planning ability, initiative on the job and overall work performance are positively correlated with each other and found to be significant. Despite of having positive correlation, the two measures of job performance i.e. dependability \& ability to get along with others are non significant. The HR practice measure Performance evaluation process and job performance measures viz. quality of work performance, amount of effort expanded on the job, speed on job, quality of the work, capacity of work performance, care in handling company property, ability to work without supervision, ability to handle different jobs, ability to get along with others, attendance \& punctuality, planning ability, initiative on the job and overall work performance are positively correlated with each other and found to be significant. Despite of having positive correlation, the only one measure of job performance i.e. dependability are non significant. The HR practice measure promotion and job performance measures viz. quality of work performance, amount of effort expanded on the job, speed on job, quality of the work, capacity of work performance, care in handling company property, ability to get along with others, attendance \& punctuality, planning ability, initiative on the job and overall work performance are positively correlated with each other and found to be significant. Despite of having positive correlation, the three measures of job performance i.e. dependability, ability to work without supervision, ability to handle different jobs are non significant. Hence on the basis of above discussion, it states that the employees working in steel and power sector of Chhattisgarh perceives HR practices (compensation, performance evaluation process, promotion) are positively correlated with measures of job performance. The dependability, a measure of job performance founds to be non significant with all three HR practices (compensation, performance evaluation process \& promotion). The job performance measure ability to get along with others is non significant with compensation. The job performance measure ability to work without supervision \& ability to handle different jobs is non significant with promotion.

The previous studies also supports the current study that there occurs a relationship between job performance and HR practice measures.

\section{Descriptive Statistics:}

Table1: Shows Means, Standard deviations, Skewness \& Kurtosis $(\mathrm{N}=512)$ on measures of Job performance \& HR Practices

\begin{tabular}{|l|l|l|l|l|}
\hline Dimensions & Mean & $\begin{array}{l}\text { Standard } \\
\text { Deviation }\end{array}$ & Skewness & Kurtosis \\
\hline Compensation & 22.7656 & 4.57764 & .022 & -.223 \\
\hline Performance Evaluation Process & 17.7578 & 3.00488 & -.487 & .466 \\
\hline Promotion & 10.5000 & 1.73374 & -.081 & -.619 \\
\hline Quality of the work Performance & 3.8672 & .80479 & -.840 & .581 \\
\hline Amount of Effort expanded on the job & 4.0469 & .76988 & -1.217 & 3.030 \\
\hline Speed on Job & 3.9844 & .83920 & -.928 & 1.414 \\
\hline Quality of the work & 4.0391 & .87050 & -.862 & .285 \\
\hline Capacity of work Performance & 4.0938 & .82464 & -.764 & .200 \\
\hline Care in Handling Company Property & 4.1484 & .87666 & -.923 & .562 \\
\hline Ability to work without Supervision & 3.9922 & .89789 & -.571 & -.175 \\
\hline Ability to handle different Jobs & 3.8437 & .88861 & -.630 & .107 \\
\hline Dependability & 3.5000 & 1.06904 & -.521 & -.368 \\
\hline Ability to get along with others & 4.1016 & .83785 & -.674 & -.158 \\
\hline Attendance and Punctuality & 4.2031 & .85193 & -.859 & .015 \\
\hline Planning ability & 4.0703 & .80297 & -.674 & .584 \\
\hline Initiative on the Job & 4.0234 & .90629 & -.680 & -.028 \\
\hline Overall Work Performance & 4.1094 & .71039 & -.818 & 1.264 \\
\hline
\end{tabular}


Table 2: Shows HR practices correlations between the measures of job performance

\begin{tabular}{|c|c|c|c|}
\hline Dimensions & Compensation & Performance Evaluation Process & Promotion \\
\hline Compensation & - & .614 & .477 \\
\hline Performance Evaluation Process & - & - & .495 \\
\hline Promotion & - & - & - \\
\hline Quality of the work Performance & $.217^{\prime \prime}$ & $.242 ”$ & $.115^{\prime \prime}$ \\
\hline Amount of Effort expanded on the job & $.265^{\prime \prime}$ & $.343^{\prime \prime}$ & $.194^{\prime \prime}$ \\
\hline Speed on Job & $.252^{\prime \prime}$ & $.371^{\prime \prime}$ & $.151^{\prime \prime}$ \\
\hline Quality of the work & $.226^{\prime \prime}$ & $267^{\prime \prime}$ & $.117^{\prime \prime}$ \\
\hline Capacity of work Performance & $.286^{\prime \prime}$ & $297^{\prime \prime}$ & $.170^{\prime \prime}$ \\
\hline Care in Handling Company Property & $.249 ”$ & $.326^{\prime \prime}$ & $.136^{\prime \prime}$ \\
\hline Ability to work without Supervision & $207^{\prime \prime}$ & $.144^{\prime \prime}$ & .078 \\
\hline Ability to handle different Jobs & $.172 ”$ & $.159 \%$ & .112 \\
\hline Dependability & .066 & .009 & .000 \\
\hline Ability to get along with others & .043 & $.116^{\prime \prime}$ & $.164^{\prime \prime}$ \\
\hline Attendance and Punctuality & $.175^{\prime \prime}$ & $.194 ”$ & $.164^{\prime \prime}$ \\
\hline Planning ability & $.266^{\prime \prime}$ & $.338^{\prime \prime}$ & $.188^{\prime}$ \\
\hline Initiative on the Job & $.156^{\prime \prime}$ & $.295^{\prime}$ & $.157^{\prime \prime}$ \\
\hline Overall Work Performance & $.333^{\prime \prime}$ & $.320^{\prime \prime}$ & $.178^{\prime}$ \\
\hline
\end{tabular}

'Correlation is significant at the 0.01 level ( 2 tailed).

'Correlation is significant at the 0.05 level ( 2 tailed).

\section{References:}

[1]. Arvey, R.D. \& Murphy, K.R. (1998) Performance evaluation in work settings, Annual Review of Psychology, Vol (49), pp. 141 168.

[2]. Barney, J. (1991). Firm resources and sustained competitiveadvantage. Journal of Management, 17,99-120.

[3]. Borman, W.C. \& Motowidlo, S.J. (1993) Expanding the criterion domain to include elements of contextual performance. In Schmitt \& W. Borman (Eds.), Personnel selection in organizations New York: Jossey- Bass, pp. 71 - 98.

[4]. Borman, W.C. \& Motowidlo, S.J. (1997) Task performance and contextual Performance: The meaning for Personnel selection Research, Human Performance, Vol. 10, pp. 199 - 109.

[5]. Bruederl, J., Preisendoerfer, P., \& Ziegler, R. (1992). Survival chances of newly founded business organizations. American Sociological Review, 57, 227-242.

[6]. Campbell, J.P.; gasser, M.; Oswald, F. (1996) The substantive nature of job performance variability, In K. Murphy (Ed.), Individual differences and behaviour in organzations. Hillssale, NJ:Erlbaum.

[7]. Camplbell, J.P.; gasser, M.; Oswald, F. (1996) The substantive nature of job performance variability, In K. Murphy (Ed.), Individual differences and behaviour in organizations. Hillsdale, NJ: Erlbaum.

[8]. Cooper, R.K. \& sawaf, A. (1997) Executive EQ: Emotional Intelligence in Leadership and Organisations, Grosset/Putnum, New York, NY.

[9]. Delery, J.E. and Doty, D.H. (1996) 'Modes of Theorizing in Strategic Human Resource Management: Tests of Universalistic. Contingency and Configurational Performance Predictions'. Academy of Management Journal. 39: 802-35.

[10]. Gimeno, J., T. B. Folta, A.C. Cooper, \& C.Y. Yoo (1997). Survival of the fittest? Entrepreneurial human capital and the persistence of underperforming firms. Administrative Science Quarterly 42: 750-783.

[11]. Grossman, R. J., 2000. Measuring up: Appropriate Metrics Help HR Prove its Worth, HR Magazine.

[12]. Harel, G.H. \& Tzafrir, S.S. (1999), 'The Effect of Human Resource Management Practices on the Perceptions of Organizational and Market Performance of the Firm',Human Resource Management, Vol.38, pp.185-200.

[13]. Harter, J., Schmidt, F., \& Hayes, T. (2002). Business-unit-level relationships between employee satisfaction, employee engagement, and business outcomes: A meta-analysis. Journal of Applied Psychology, 87, 268-279.

[14]. Howard, A. (1995) The changing nature of work. San Francisco, CA: Jossey-Bass

[15]. Huselid, M. (1995), 'The Impact of Human Resource Management Practices on Turnover Productivity, and Corporate Financial Performance', Academy of Management Journal, Vol.38, No.3, pp.635-672.

[16]. Ilgen, D.R. \& Pulakos, E.D. (1999) The changing nature of performance: Implications for staffing , motivation, and development.. San Francisco: Jossey- Bass

[17]. Ilgen, D.R. \& Schneider, J. (1991) Performance Measurement: A multidiscipline view. In C.L. Cooper \& I.T. Roberttson (Eds.) International Review of Industrial and Organisational Psychology, Chichester, Wiley.

[18]. Kanfer, R. \& Ackerman, P.L. (1989) Motivation \& cognitive abilities: An integrative/aptitude - treatment interaction approach to skill acquisition. Journal of applied Psychology, Vol. (74), pp. $657-690$

[19]. Khurram Shezad, Sajid Bashir, Muhamad I Rammay. Internatianal Review of Business Research Papers, Vol.4 No.2 March 2008 PP 302-315.

[20]. Luthans, K. W., \& Sommers, S. M. (2005). The impact of high performance work on industry-level outcomes. Journal of Managerial Issues, 17(3), 327-345.

[21]. Motowidlo, S.J.; Borman, W.C.; \& Schit, M.J. (1997) A Theory of Individual Differences in Task and Contextual Performance, Human Performance, Vol. (10) pp. $71-83$

[22]. Motowidlo, S.J.; Borman, W.C.; \& Schmit, M.J. (1999) Performance assessment ij unique jobs. In D.R. Ilgen \& E.D. Pulakos (Eds.), The changing nature of performance, San Francisco: Jossey-Bass, pp. $56-86$

[23]. Nayyar, M.R. (1994) some Correlates of work performance perceived by first line supervisor: A study, Management and Labour studies, Vol. (19), $50-54$

[24]. Organ, D.W. (1988) A restatement of the satisfaction - performance hypothesis, Journal of Management, Vol. (14), pp. 547-557

[25]. Pablos. 2002. Evidenc of Intellectual Capital Measurement from Asia, Europe and the Middle East. Journal of Intellectual Capital. 
[26]. Park, H. J., Mitsuhashi, H., Fey, C. F. and Bjorkman, I. (2003). The effect of human resource management practices on Japanese MNC subsidiary performance: a practical mediating model, International Journal of Human Resource Management, 14(8), 13911406.

[27]. PwC. 2008. HR management: Key trends in human capital .

[28]. Qadar Bakhsh Baloch, Nazim Ali, Tahir Sultan Kiani, Anjum Ahsan, Awais Mufty Relationship between HR Practices and Perceived Employees' Performance of Bankers in NWFP, Pakistan (An Empirical Evidence). European Journal of Social Sciences Volume 18, Number 2 (2010).

[29]. Roe, R.A. (1999) work performance: A multiple regulation perspective. In: G. Cooper and I.T. Robertson (Eds.), International Review of Industrial and Organisational Psychology, Chichester: wiley, pp. 231- 235.

[30]. Romanoff, K. (1989) The ten commandments of performance management, Personnel, January, Vol. (66), pp. 24 - 28

[31]. Soharab Ahmad \& Khurram Shezad. African Journal of Business Management Vol 5(13) PP 5249-52553 4th july 2011.

[32]. Stuart,A.D. \& Pauquet, A. (2001). Emotional intelligence as a determinant of leadership potential. Journal of Industrial Psychology, 27(3), 30-34.

[33]. Teeseema M. and Soeters J.(2006). Challenges and prospects of HRM in developing countries: testing the HRM performance link in Eritrean Civil Service International Journal of Human Resource Management 17(1), 86-105.

[34]. Visveswaran, C. \& Ones, D.S. (2000) Perspectives on models of job performance, International Journal of selection and Assessment, Vol.(8) pp. 216-226

[35]. Wright, P. M., Garden, T. M. and Moynihan, L. M. (2003). The impact of HR practices on the performance of business units, Human Resource Management Journal, 13(3), 21-36.

[36]. Zwell, M. \& Ressler, R. 2000. Powering the human drivers of financial performance. Strategic Finance. 